\title{
ДІАГНОСТИКА Й ФІТОРЕМЕДІАЦІЯ НАФТОЗАБРУДНЕНИХ ПРИРОДНИХ І ШТУЧНИХ НАЗЕМНИХ ЕКОСИСТЕМ СТАРОСАМБІРСЬКОГО НАФТОВОГО РОДОВИЩА
}

\author{
Подан I. I., Джура Н. М.
}

\section{ВСТУП}

Нафтовидобувна і нафтопереробна галузі промисловості за наслідками впливу на природне середовище посідають одне з найвагоміших місць. Транспортні аварії у Світовому океані, аварії на міжнародних автомагістралях, викиди відходів перероблення нафти в атмосферу та грунт призводять до забруднення довкілля.

В Україні щільна мережа об'єктів нафтопродуктозабезпечення. Практично вся територія країни перебуває під потенційною загрозою нафтового забруднення. Старосамбірське нафтове родовище (далі - СНР) розташоване на території Старосамбірського району Львівської області. Видобуток нафти на території родовища було розпочато в грудні 1969 p. Внаслідок інтенсивного і довготривалого нафтовидобутку й різних видів будівництва природний рельєф родовища зазнав сильної антропогенної трансформації, виникли екологічні проблеми в екосистемах, зокрема в їхніх найважливіших компонентах - грунтах і рослинному покриві ${ }^{1}$.

На забруднених нафтою територіях формується специфічний мікроклімат, зумовлений мікрорельєфом, складом субстрату, порушеним водним i зміненим температурним режимами. Чорне забарвлення нафтозабруднених грунтів призводить до надмірного поглинання сонячної радіації. Нафтові виливи утворюють на поверхні грунту щільну, в'язку бітумінозну кірку. Забруднення грунтів нафтою зумовлює зміни їхніх фізико-хімічних властивостей.

Склеювання структурних частин грунту нафтою призводить до значного зростання в'язкості й щільності грунтової маси, що погіршує його повітряно-водний режим. Грунти, просочені нафтопродуктами, втрачають здатність вбирати й затримувати вологу. У таких грунтах створюються анаеробні умови, змінюється окисно-відновний потенціал, вуглецево-азотний баланс грунту й порушується кореневе живлення рослин ${ }^{2,3}$.

\footnotetext{
1 Джура Н. М., Подан I. І. Екологічні наслідки довготривалого нафтовидобутку на Старосамбірському родовищі. Вісник Львівського університету. Серія біологічна. 2017. Вип. 76. C. 120-127. DOI: http://dx.doi.org/10.30970/vlubs.2017.76.15.

${ }^{2}$ Джура Н. М., Подан I. I. Екологічна безпека територій Старосамбірського нафтового родовища. Екологічна безпека держави : збірка тез XIV Всеукраїнської науково-практичної конференції молодих учених і студентів, 23 квітня 2020 р. Київ, 2020. С. 68.
} 
Забруднення грунтів нафтою спричинює деградацію земель, а також створює небезпеку проникнення полютантів у живильні ланцюги, однією з ланок яких є людина. Це зумовлює гостру необхідність пошуку ефективних і екологічно безпечних методів очищення довкілля від забруднень нафтою. Все вищезгадане свідчить про актуальність дослідження й вивчення оптимальних умов для фіторемедіації нафтозабруднених територій.

\section{1. Екологічна оцінка нафтозабруднених екосистем \\ в умовах Старосамбірського нафтового родовища}

Ми провели тривалий моніторинг природних екосистем Старосамбірського нафтового родовища зі зруйнованим біогеоценотичним покривом. Унаслідок розроблення нафтового родовища рослинність цього регіону зазнала значних антропогенних змін. Вивчали рослинність й аналізували грунти ділянок нафтових свердловин № 60, 65, 76 СНР (рис. 1).

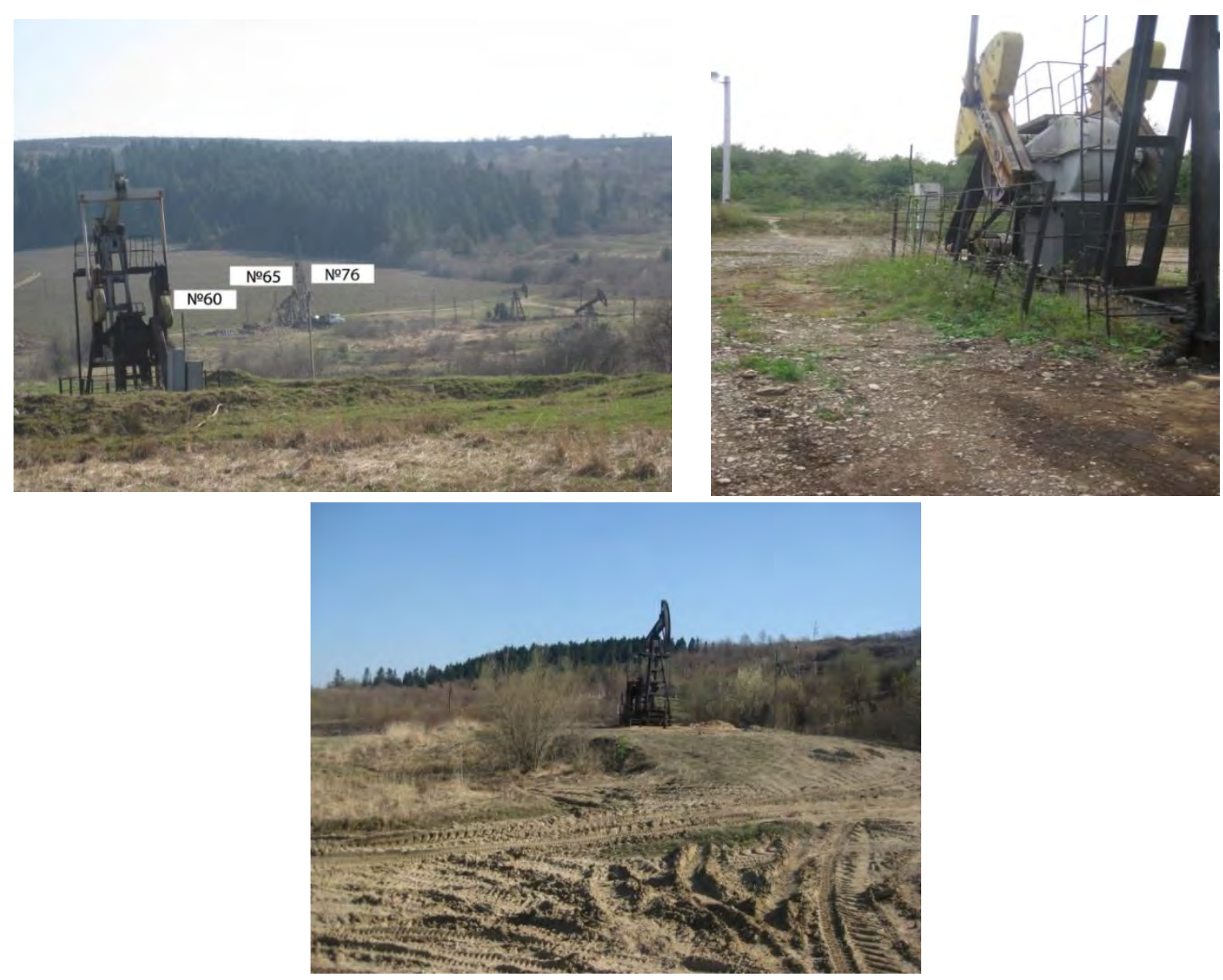

Рис. 1. Старосамбірське нафтове родовище

3 Клімова Н. Деякі питання методики оцінки стану забруднення грунтів унаслідок нафтогазовидобутку. Вісник Львівського університету. Серія географічна. 2006. Вип. 33. С. 144-151. 
Складено видовий перелік фітоценозів ${ }^{4}$ Старосамбірського родовища. На основі ідентифікації типових представників рослинного покриву встановлено тип фітоценозів цього регіону: флористично бідні рудеральні угруповання 3 домінуванням довгокореневищних травбагаторічників (рис. 2).

Площинно домінують злаки, серед яких Роa аппиа L., Elytrigia repens (L.) Nevski, Calamagrostis arundinacea (L.) Roth, Setaria viridis (L.) Beauv.; наявні представники родини Cyperaceae, зокрема Carex hirta L. Толерантні до нафтового забруднення види рослин можуть бути рекомендовані для фіторемедіаційних технологій деградованих грунтів цього регіону ${ }^{5}$.
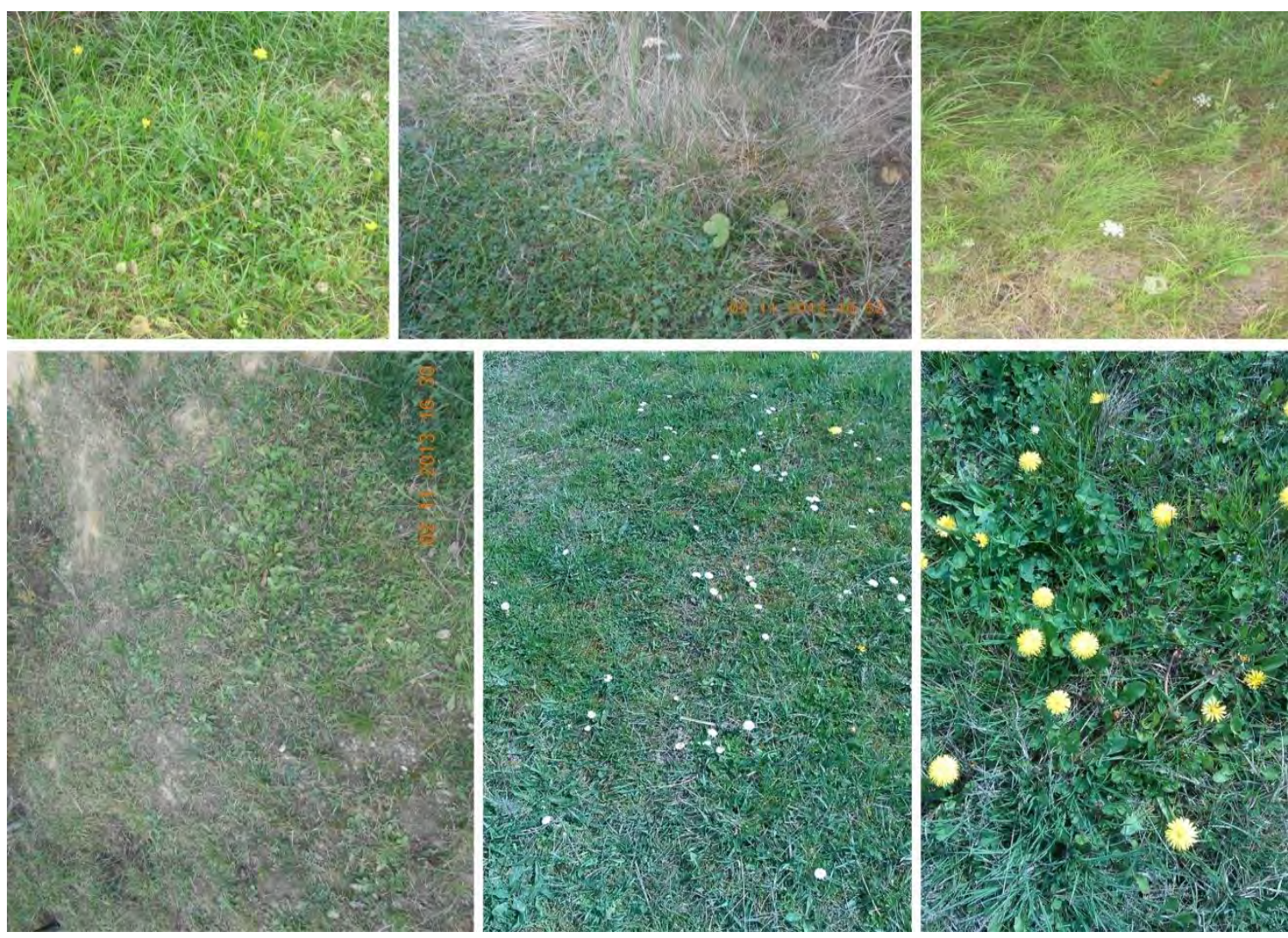

\section{Рис. 2. Рослинний покрив Старосамбірського нафтового родовища}

Тривалість вегетаційного періоду рослин, їхній видовий склад, продуктивність рослинного покриву залежать від температури грунту, адже іiі підвищення може негативно впливати на здатність кореневої системи засвоювати поживні речовини, на інтенсивність фотосинтезу, дихання, транспірацію та інші фізіологічні процеси в рослинах.

\footnotetext{
${ }^{4}$ Определитель высших растений Украины / под ред. Д.Н. Доброчаева, М.И. Котова и др. Киев : Наукова думка, 1987.548 с.

5 Джура Н. М. Подан I. I. Екологічні наслідки довготривалого нафтовидобутку на Старосамбірському родовищі. Вісник Львівського університету. Серія біологічна. 2017. Вип. 76. C. 120-127. DOI: http://dx.doi.org/10.30970/vlubs.2017.76.15.
} 
Температура грунту залежить від температури повітря та від стану грунту. Головним джерелом тепла $є$ сонячна енергія. Незначна кількість тепла надходить до грунту із глибинних шарів Землі, а також утворюється внаслідок розкладання органічних речовин (перегною, рослинних решток, побутових міських відходів). Теплопоглинальна здатність грунту характеризує його можливості поглинати і відбивати сонячну енергію. Цей показник називають альбедо (кількість короткохвильової сонячної радіації, відбитої поверхнею грунту, що виражається у відсотках загальної сонячної радіації, яка досягає поверхні Землі). Чим вище альбедо, тим більше грунт віддзеркалює енергії й тим менше нагрівається. Ця величина найістотніше залежить від забарвлення грунту ${ }^{6}$.

Отримані результати підтверджують те, що нафта, змінюючи забарвлення грунту на чорне, зменшує альбедо. Тому нафтозабруднені грунти СНР мали вищу температуру, як порівняти 3 контролем, і нижчу порівняно $з$ тими, на яких були рослини (табл. 1). Рослинний покрив запобігає перегріванню деградованих нафтозабруднених грунтів. За участю рослин у всіх досліджуваних точках температура грунту була нижчою в середньому на $3-5^{\circ} \mathrm{C}$.

Таблиця 1

Температура нафтозабруднених грунтів

Старосамбірського родовища $\left( \pm 1,1^{\circ} \mathrm{C}\right)$

\begin{tabular}{|c|c|c|c|c|c|c|c|}
\hline \multirow{2}{*}{\multicolumn{2}{|c|}{ Досліджувані }} & \multicolumn{2}{|c|}{$\begin{array}{c}\text { Червень, } 2016 \text { р. } \\
\text { to }^{\circ} \text { пов. } 24,8^{\circ} \mathrm{C}\end{array}$} & \multicolumn{2}{|c|}{$\begin{array}{c}\text { Вересень, } 2016 \text { p. } \\
\text { to }^{\circ} \text { пов. } 20,3{ }^{\circ} \mathrm{C}\end{array}$} & \multicolumn{2}{|c|}{$\begin{array}{c}\text { Березень, } 2017 \text { p. } \\
\text { to }^{\circ} \text { пов. 5,3 }{ }^{\circ} \mathrm{C}\end{array}$} \\
\hline & & \multirow{2}{*}{$\begin{array}{c}\begin{array}{c}\text { без } \\
\text { рослин }\end{array} \\
22,2\end{array}$} & \multirow{2}{*}{\begin{tabular}{|c|}
$\begin{array}{c}3 \\
\text { рослинами }\end{array}$ \\
20,7
\end{tabular}} & \multirow{2}{*}{$\begin{array}{c}\begin{array}{c}\text { без } \\
\text { рослин }\end{array} \\
20,0\end{array}$} & \multirow{2}{*}{$\begin{array}{c}\begin{array}{c}3 \\
\text { рослинами }\end{array} \\
19,5\end{array}$} & \multirow{2}{*}{$\begin{array}{c}\begin{array}{c}\text { без } \\
\text { рослин }\end{array} \\
3,2\end{array}$} & \multirow{2}{*}{$\begin{array}{c}\begin{array}{c}3 \\
\text { рослинами }\end{array} \\
-\end{array}$} \\
\hline \multirow{4}{*}{$\begin{array}{c}\text { Свердловина } \\
\text { № } 60\end{array}$} & 0 & & & & & & \\
\hline & 1 & 26,2 & 22,1 & 24,2 & 20,0 & 6,6 & - \\
\hline & 2 & 25,9 & 21,9 & 24,0 & 19,9 & 7,1 & - \\
\hline & 3 & 26,8 & 22,5 & 23,9 & 20,0 & 7,4 & - \\
\hline \multirow{4}{*}{$\begin{array}{c}\text { Свердловина } \\
\text { № } 65\end{array}$} & 0 & 22,2 & 20,7 & 20,0 & 19,5 & 3,2 & - \\
\hline & 1 & 28,1 & 23,0 & 25,2 & 21,1 & 7,1 & - \\
\hline & 2 & 27,5 & 22,9 & 24,7 & 20,7 & 6,9 & - \\
\hline & 3 & 27,8 & 23,4 & 24,8 & 20,5 & 7,1 & - \\
\hline \multirow{4}{*}{$\begin{array}{c}\text { Свердловина } \\
\text { № } 76\end{array}$} & 0 & 22,2 & 20,7 & 20,0 & 19,5 & 3,2 & - \\
\hline & 1 & 27,3 & 24,1 & 24,6 & 21,2 & 6,0 & - \\
\hline & 2 & 27,6 & 22,8 & 24,4 & 21,0 & 6,9 & - \\
\hline & 3 & 25,3 & 21,9 & 24,5 & 22,1 & 6,8 & - \\
\hline
\end{tabular}

Умовні позначення: 0 - контроль (грунт без нафти); 1- грунт біля свердловини; 2 - грунт за 10 м від свердловини; 3 - грунт за 20 м від свердловини.

\footnotetext{
${ }^{6}$ Киреева Н. А., Мифтахова А. М., Кузяхметов Г. Г. Рост и развитие сорных растений в условиях техногенного загрязнения почвы. Вестник Башкирского университета. 2001. № 1. С. 32-34.
} 
Тепловий i водний режими грунту визначають динаміку грунтотвірних процесів. Відомо, що вода має більшу теплоємність, ніж компоненти грунту, тож для підвищення температури вологого грунту потрібно більше сонячної енергії. Тому сухі піщані й супіщані грунти швидше нагріваються і швидше охолоджуються.

Грунти Старосамбірського родовища переважно глинисті, вирізняються більшою теплоємністю, у вологому стані навесні повільніше нагріваються, а восени довше тримають тепло.

Реакція грунтового розчину визначає умови життєдіяльності рослин $\mathrm{i}$ мікроорганізмів, які проживають у грунті, має значний вплив на біотичні й хімічні процеси, визначає характер вмісту поживних речовин для рослин, впливає на закріплення гумусу, рухливість колоїдних фракцій, мінеральних елементів. Крім того, величина $\mathrm{pH} \epsilon$ фактором, який характеризує силу миттєвої дії кислот або лугів на грунт і рослини. Від значення $\mathrm{pH}$ залежить надходження мінеральних речовин у рослини ${ }^{7,8}$. Ми досліджували реакцію грунтового розчину нафтозабруднених грунтів СНР (табл. 2).

Таблиця 2

Актуальна кислотність (рН Н (без рослинного покриву) Старосамбірського нафтового родовища

\begin{tabular}{|c|c|c|c|}
\hline Варіанти* & $\begin{array}{c}\text { Червень, } \\
\mathbf{2 0 1 6} \text {. }\end{array}$ & $\begin{array}{c}\text { Вересень, } \\
\mathbf{2 0 1 6} \mathbf{~ p . ~}\end{array}$ & $\begin{array}{c}\text { Березень, } \\
\mathbf{2 0 1 7} \mathbf{~ p . ~}\end{array}$ \\
\hline \multicolumn{4}{|c|}{ Свердловина № 76} \\
\hline 1 & 7,2 & 7,3 & 7,9 \\
\hline 2 & 6,4 & 6,8 & 8,2 \\
\hline 3 & 7,1 & 7,5 & 8,1 \\
\hline \multicolumn{4}{|c|}{ Свердловина № 60} \\
\hline 1 & 7,7 & 7,7 & 7,8 \\
\hline 2 & 7,3 & 7,8 & 8,0 \\
\hline 3 & 7,6 & 7,8 & 8,1 \\
\hline \multicolumn{5}{|c|}{ Свердловина № 65} \\
\hline 1 & 6,3 & 6,8 & 7,9 \\
\hline 2 & 7,2 & 7,5 & 8,1 \\
\hline 3 & 6,8 & 7,6 & 8,1 \\
\hline
\end{tabular}

Умовні позначення: 1- грунт біля свердловини; 2 - грунт за 10 м від свердловини; 3 - грунт за 20 м від свердловини; * $\mathrm{pH}$ контрольного варіанту - 6,4.

\footnotetext{
${ }^{7}$ Киреева Н. А., Мифтахова А. М., Кузяхметов Г. Г. Рост и развитие сорных растений в условиях техногенного загрязнения почвы. Вестник Башкирского университета. 2001. № 1. С. 32-34.

${ }^{8}$ Концепція екологічного нормування допустимого антропогенного навантаження на грунтовий покрив / за ред. С. А. Балюка, М. І. Ромащенка. Київ : Аграрна наука, 2004. 34 с.
} 
3 отриманих результатів видно, що нафта дещо підлужнює рН грунту порівняно 3 контролем $(\mathrm{pH}=6,4)$. Можливо, це відбувається внаслідок мікробіологічного розкладання бітумінозних речовин нафти завдяки розкладенню органічних залишків. У літературі $є$ дані про те, що нафтозабруднені грунти містять високі концентрації солей натрію. Натрій, включаючись у грунтовий поглинальний комплекс, витісняє катіони, які визначають грунтову кислотність, викликаючи тим самим підлужнення грунтів (значення $\mathrm{pH}$ водної витяжки грунту може збільшуватися від 5,0 до 8,3) $)^{9,10}$.

Оперативну інформацію про фітотоксичність грунту можна отримати, використовуючи як тест-об'єкти насіння й проростки рослин. Тестфункції, що використовують у біотестуванні, досить різноманітні: динаміка проростання насіння, відсоток схожості, довжина головного й бічних коренів, висота пагона тощо. На основі цих параметрів визначають фітотоксичний ефект грунту ${ }^{11,12}$.

Під час визначення фітотоксичності відібраних проб грунту СНР ми аналізували відносну схожість насіння (далі - ВCH), відносну довжину кореня (далі - ВДК) і відносну висоту пагона (далі - ВВП) фітотесту Linum usitatissimum L. Встановлені залежності між початковими ростовими параметрами тест-культури L. usitatissimum і токсичністю нафтозабруднених грунтів СНР (рис. 3).

3 отриманих результатів видно, що найтоксичнішими були проби грунту, відібрані на відстані 10 і 20 м від свердловин (варіант 2 і 3): ВCH і ВВП становили менше ніж 20\% (свердловини № 60 і 65). Пагон L. usitatissimum проявив більш виражену реакцію на токсичність нафтозабруднених грунтів СНР, тоді як корінь - високу чутливість і в більшості варіантів не виростав. Зі збільшенням токсичності нафтозабруднених грунтів (на відстані 10 і 20 м від свердловин) ріст пагона поступово пригнічувався. Ця залежність має лінійний характер. Такий високий фітотоксичний ефект вказує на максимальний рівень токсичності досліджуваних проб грунту, що може бути обумовлено додатковим навантаженням. Оскільки транспортування нафти зі СНP проводиться автотранспортом, там постійно стаються розливи нафти під час наповнювання автоцистерн і витоптування грунту; як наслідок -

\footnotetext{
9 Клімова Н. Деякі питання методики оцінки стану забруднення грунтів унаслідок нафтогазовидобутку. Вісник Львівського університу. Серія географічна. 2006. Вип. 33. С. 144-151.

${ }^{10}$ Pavlychenko A., Kovalenko A. The investigation of rock dumps influence to the levels of heavy metals contamination of soil. Mining of Mineral Deposits. Leiden, The Netherlands: CRC Press. Balkema, 2013. P. 237-238. DOI https://doi.org/10.1201/b13157-7.

11 Горова А., Кулина С. Оцінка токсичності грунтів Червоноградського гірничопромислового району за допомогою ростового тесту. Вісник Львівського університету. Серія біологічна. 2008. Вип. 48. С. 189-194.

${ }^{12}$ Губачов О. І. Особливості використання рослин для біотестування грунтів з метою визначення рівня екологічної безпеки промислових територій. Наук. вісн. КУЕІТУ. Нові технології. 2010. № 3 (29). C. 164-171.
} 
грунти ущільнюються, змінюється їхній гідрологічний режим, деградує рослинний покрив.
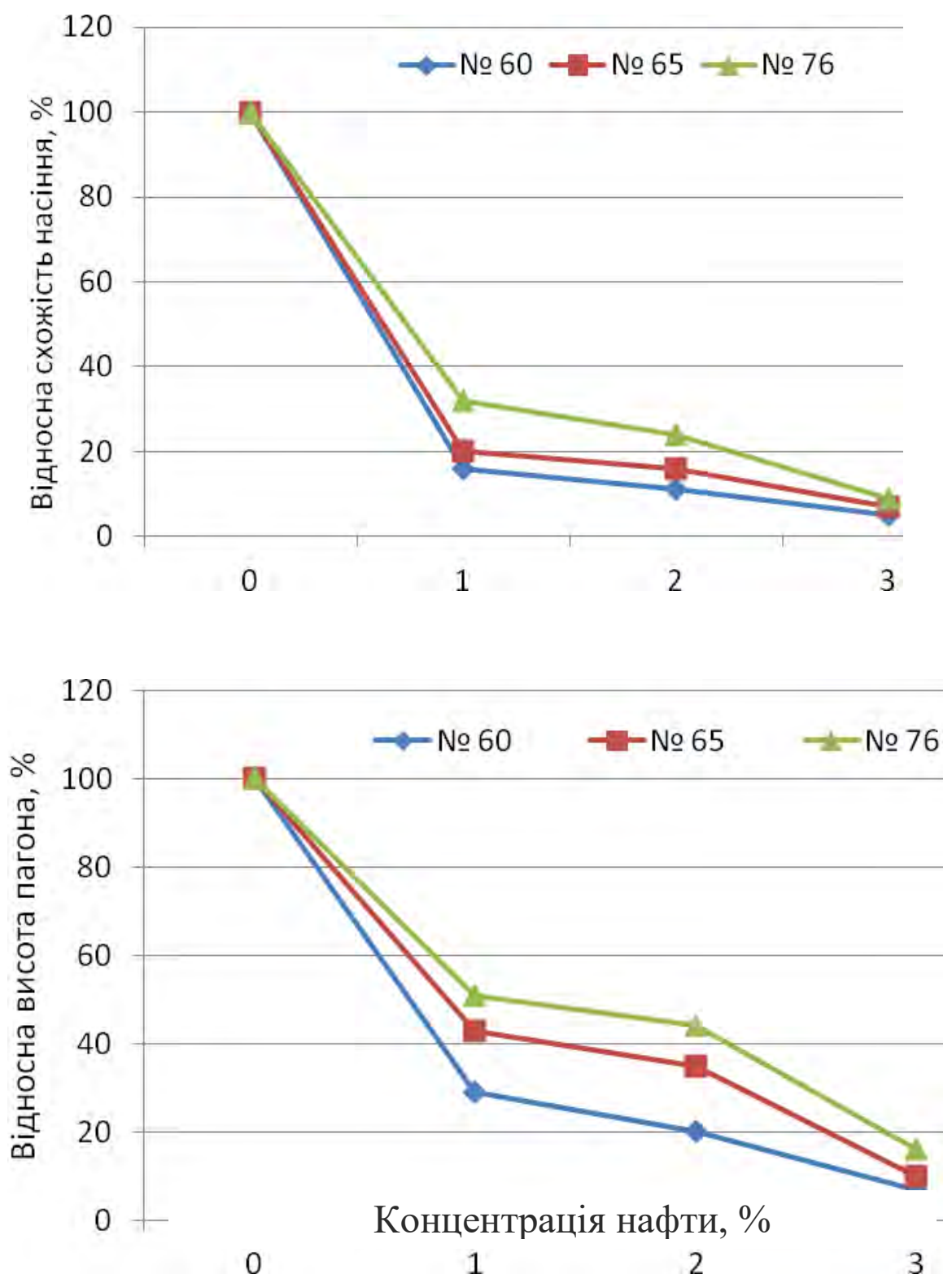

Рис. 3. Фітотоксичність нафтозабруднених грунтів Старосамбірського родовища свердловин № 60, 65, 76, виражена тест-показниками $L$. usitatissimum

(різниця між відповідними показниками достовірна при $\mathbf{p}<0,05$ )

0 - контроль (грунт без нафти); 1- грунт біля свердловини; 2 - грунт за 10 м від свердловини; 3 - грунт за 20 м від свердловини 
Для порівняння токсичності за ростовим фітотестом використовували шкалу рівнів токсичності грунтів (табл. 3$)^{13}$.

Шкала рівнів токсичності грунтів ${ }^{14}$

\begin{tabular}{|c|l|}
\hline $\begin{array}{c}\text { Рівні пригнічення } \\
\text { ростових процесів } \\
\text { (фітотоксичний ефект), \% }\end{array}$ & \multicolumn{1}{c|}{ Рівень токсичності } \\
\hline $0-20$ & $\begin{array}{l}\text { Відсутність або слабкий рівень } \\
\text { токсичності }\end{array}$ \\
\hline $20,1-40$ & Середній рівень \\
\hline $40,1-60$ & Вище середнього рівня \\
\hline $60,1-80$ & Високий рівень \\
\hline $80,1-100$ & Максимальний рівень \\
\hline
\end{tabular}

У попередніх дослідженнях було виявлено універсальність i чутливість фітотестів Linum usitatissimum L. i Helianthus annuus L. для оцінки токсичності нафтозабруднених грунтів ${ }^{15}$.

Практичне використання розробленого експрес-методу передбачало доцільність його застосування для фітооцінки токсичності нафтозабруднених грунтів, у цьому випадку - Старосамбірського нафтового родовища. На основі отриманих результатів (див. рис. 3) виведеної калібрувальної кривої та шкали рівнів токсичності грунтів (див. табл. 3) встановлено ступінь забруднення й приблизну концентрацію нафти в досліджуваних пробах грунту СНР:

- свердловина № 60 - максимальний рівень токсичності, дуже сильне забруднення (понад 10\% нафти). Ця свердловина в експлуатації найдовше (з 1971 р.), розташована біля дороги, отримує ще додатковий вплив від автотранспорту, тому фітотоксичність грунтів максимальна.

- Свердловина № 65 - високий рівень токсичності, сильне забруднення (8-10\% нафти).

- Свердловина № 76 - рівень токсичності вищий за середній, середнє забруднення (6-8\% нафти).

Для достовірної кореляції між показниками фітотоксичності та кількісними характеристиками забруднювачів необхідно визначити

\footnotetext{
13 Горова А., Кулина С. Оцінка токсичності грунтів Червоноградського гірничопромислового району за допомогою ростового тесту. Вісник Львівського університету. Серія біологічна 2008. Вип. 48. С. 189-194.

14 Горова А., Кулина С. Оцінка токсичності грунтів Червоноградського гірничопромислового району за допомогою ростового тесту. Вісник Львівського університету. Серія біологічна. 2008. Вип. 48. С. 189-194.

15 Фітотестування як експрес-метод оцінки токсичності нафтозабруднених грунтів. Вісник Львівського університету. Серія біологічна. 2012. Вип. 58. С. 185-192.
} 
вміст нафтопродуктів у грунтах Старосамбірського родовища фізикохімічними методами. Проведені дослідження дають змогу зробити висновок, що грунти в регіоні потребують детального дослідження та впровадження заходів, які забезпечили б поліпшення їхнього якісного стану. Зокрема, почати можна 3 визначення оптимальних умов для проведення фіторемедіації.

\section{2. Методичні підходи до фіторемедіації нафтозабруднених грунтів в умовах штучних екосистем (модельно-польовий дослід)}

Як згадувалося вище, потреба в ремедіації забруднених територій Старосамбірського нафтового родовища висуває актуальні завдання щодо розроблення методів і технологій фіторемедіації нафтозабруднених грунтів.

Відомо, що довгокореневищні види, зокрема Carex hirta L., відзначаються найбільшою стійкістю до несприятливих умов нафтозабруднених екотопів, що дає підстави рекомендувати їх для фіторемедіації нафтозабруднених територій. Досліджено участь Faba bona Medic. (Vicia $f a b a$ L.) у відновленні нафтозабруднених грунтів. Показано, що рослини $V$. faba суттєво знижували фітотоксичність і вміст нафтопродуктів у забруднених грунтах ${ }^{16,17,18}$.

Аналіз останніх літературних джерел підтвердив важливість фітотехнології з вирощуванням міскантусу гігантського для очищення й поліпшення якості грунтів, забруднених важкими металами внаслідок військової діяльності, та використання його біомаси для виробництва твердих видів біопалива (гранул або брикетів). Міскантус гігантський (Miscánthus giganteus) - багаторічна трав'яниста інтродукована енергетична рослина, що вирізняється високою врожайністю та здатністю рости на бідних на органічні речовини й забруднених грунтах ${ }^{19}$.

Міскантус розмножується вегетативно - ризомами (rhizome), частиною кореневища, яка містить бруньки. Міскантус рекомендують вирощувати на малопродуктивних грунтах, не придатних для вирощування інших сільськогосподарських культур ${ }^{20}$.

16 Джура Н. М. Можливості використання рослинних тест-систем для біомоніторингу нафтозабруднених грунтів. Біологічні Cmyдiï. Studia Biologica. 2011. Т. 5. №3. С. $183-196$. DOI:https://doi.org/10.30970/sbi.0503.176.

17 Джура Н.М. Перспективи фіторемедіації нафтозабруднених грунтів рослинами Faba bona Medic. (Vicia faba L.). Вісник Львівського університету. Серія біологічна. 2011. Вип. 57. С. 117-124.

${ }^{18}$ Спосіб фітоочищення нафтозабруднених грунтів : пат. 60481 Україна : МПК (2011.01) А01В 79/02 (2006.01) В09С 1/00 / Н. М. Джура, О. І. Романюк, О. М. Цвілинюк, О. І. Терек. № u2010 12943 ; заявл. 01.11 .10 ; опубл. 25.06.011, Бюл. № 12.9 с.

19 Агрономічні аспекти вирощування міскантусу гігантського (Miscanthus giganteus) як сировини для виробництва твердого біопалива на забруднених внаслідок військової діяльності грунтах / Т. Р. Стефановська та ін. Біологічні студіï. 2017. Том. 11. № 3-4. С. 99-100.

20 Медков А. та ін. Вплив регуляторів росту рослин на адаптивні властивості Міскантусу гігантського (Miscanthus giganteus) для виробництва біомаси на грунтах, забруднених важкими металами. Біологічні студіï. 2017. Т. 11. № 3-4. С. 100-101. 
Відомо, що гумінові препарати стимулюють ріст і розвиток рослин і покращують якість рослинної продукції. Гуміфілд i фульвітал $\mathrm{e}$ поліфункціональними препаратами з біозахисними властивостями, що забезпечують активний ріст і розвиток культури, формування високого та якісного врожаю, підвищують стресостійкість рослин до несприятливих умов довкілля. Гуміфілд форте (антистресант на основі гумату амонію) - найактивніша форма гумату: прискорює ріст кореневої системи, поліпшує якісні показники врожаю, підвищує стійкість до різних стресів ${ }^{21}$. Проте вплив цих препаратів на ефективність вирощування міскантусу на нафтозабруднених грунтах досі не вивчався.

Досліди закладали в польових умовах поблизу Старосамбірського родовища у Львівській області. Ділянки глинистого грунту розміром $1 \mathrm{~m}^{2}$ забруднювали сирою нафтою в кількості $10 \mathrm{r} / \mathrm{m}^{2}$. Контролем був глинистий грунт без нафти. Перед висаджуванням міскантусу ризоми замочували в розчинах препаратів гуміфілд форте і фульвітал плюс. У фазі вегетації двічі проводили обприскування надземної частини рослин цими препаратами. Варіанти дослідних ділянок представлено на рисунку 4.

Вміст хлорофілів у листках рослин $є$ однією 3 найвиразніших характеристик адаптації фотосинтетичного апарату рослин до несприятливих умов довкілля. Результати попередніх досліджень показали, що в процесі вирощування міскантусу на нафтозабрудненому грунті й за впливу позакореневого обприскування гуміфілдом вміст фотосинтетичних пігментів у листках дослідних рослин залишався стабільним на всіх етапах досліджень.

Досліджували ростові показники міскантусу гігантського (Miscánthus giganteus) за впливу нафтового забруднення й гуматів (табл. 4).

Встановлено (див. табл. 4, рис. 5), що застосування фульвіталу поліпшувало ріст і розвиток міскантусу в умовах нафтового забруднення: середня висота пагонів становила 108,3 $\pm 5,1$ см (варіант № 5), а це на $25 \%$ більше, ніж за впливу нафтового забруднення без гуматів (варіант № 2). Варто підкреслити, що саме за впливу нафтового забруднення і фульвіталу (варіант № 5) спостерігали розвиток потужної кореневої системи й активне нагромадження надземної біомаси, тоді як у контролі (варіант № 3) висота пагонів міскантусу була меншою майже на $30 \%$.

Аналіз отриманих результатів вказує на стимулювальну дію одночасного впливу нафтового забруднення й фульвіталу на ростові показники міскантусу ${ }^{22}$. Причини такого ефекту потребують додаткового пояснення й вивчатимуться в подальших дослідженнях.

\footnotetext{
${ }^{21}$ Гумати - антистресова терапія для рослин. Агротехносоюз. веб-сайт. URL: www.agrotechnosouz.com.ua.

22 Подан I. І., Джура Н. М. Вплив нафтового забруднення й гуматів на ріст рослин міскантусу. Екологічні науки. Київ : ДЕА, 2019. № 2 (25). С. 182-186. DOI https://doi.org/10.32846/2306-9716-20192-25-30. 
Варіант № 1 Варіант № 2 Варіант № 3

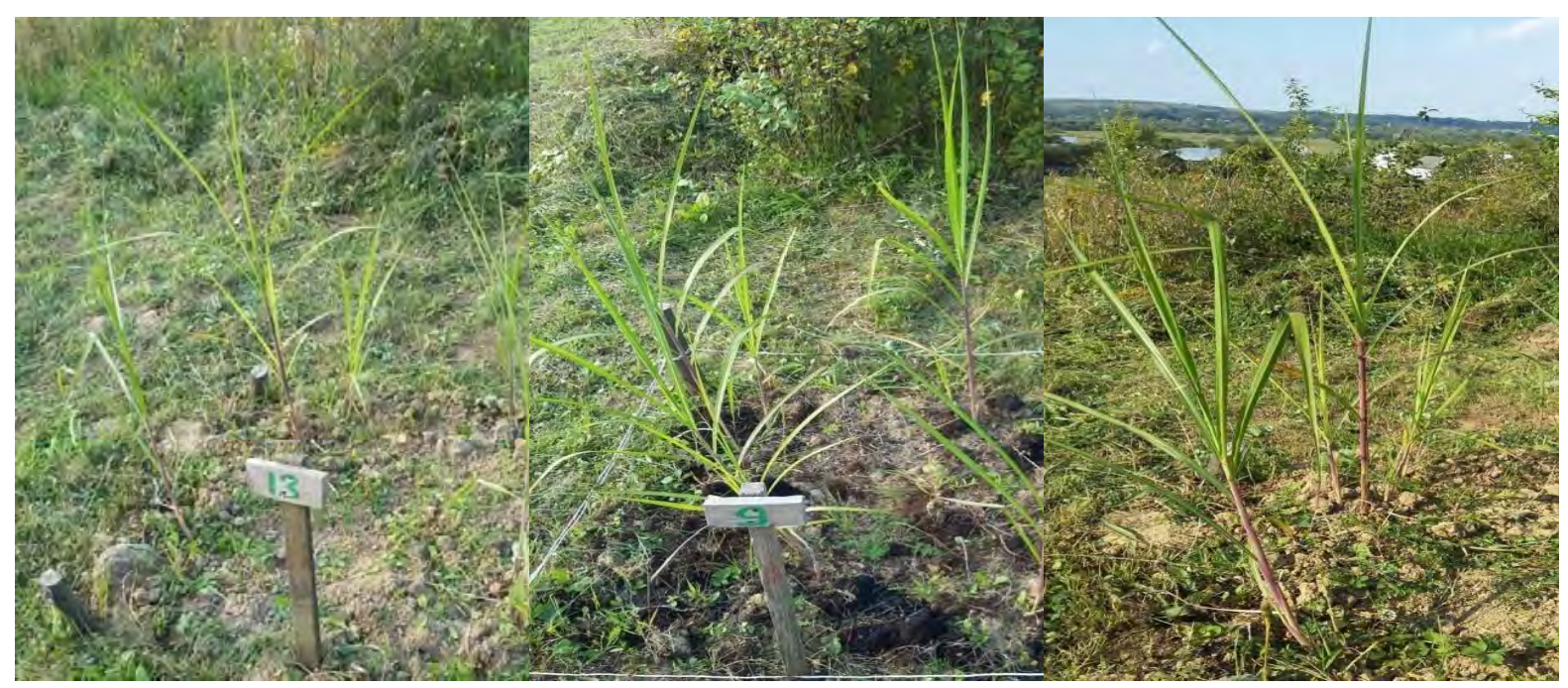

Варіант № 4

Варіант № 5

Варіант № 6

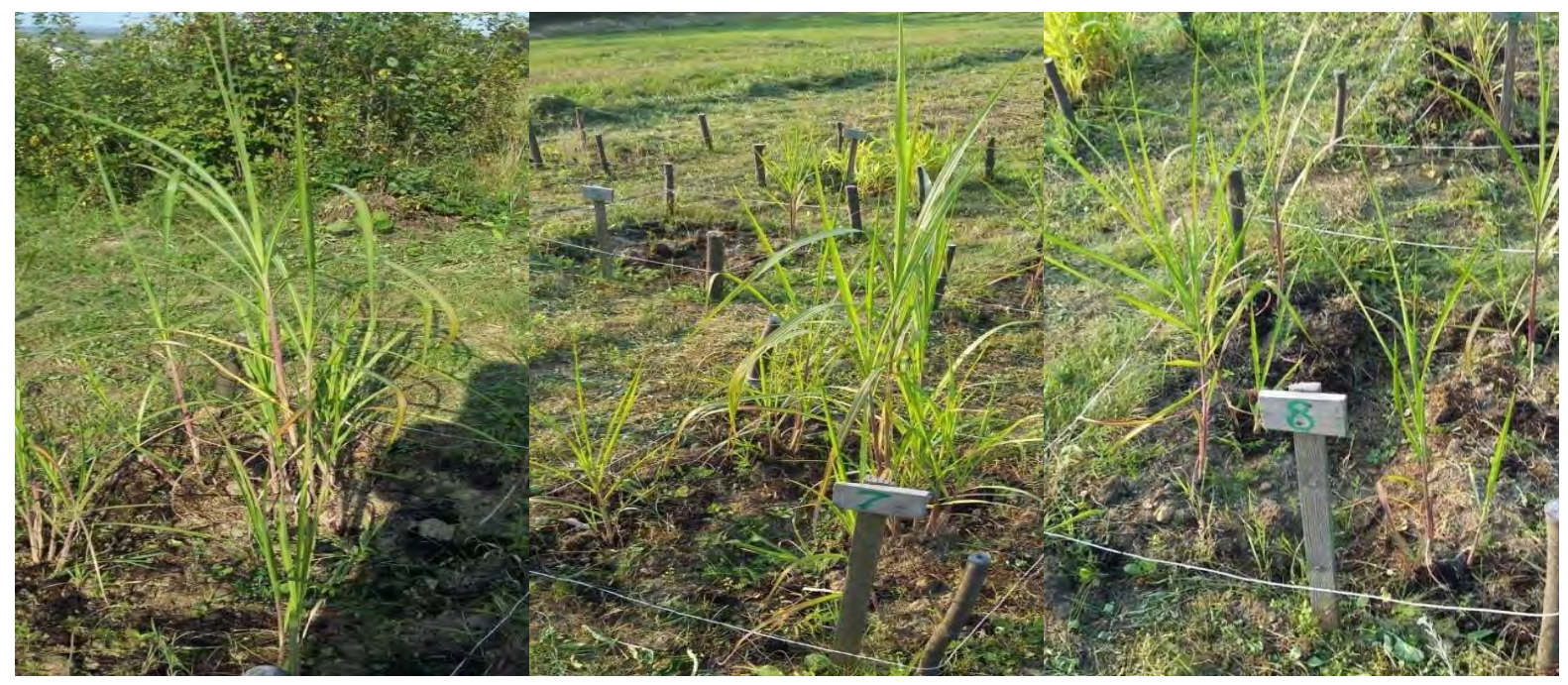

\section{Рис. 4. Дослідна ділянка для вивчення впливу нафтового забруднення й гуматів на ріст рослин міскантусу (штучні екосистеми)}

№ 1 - контроль (грунт без нафти, рослини без гуматів); № 2 - нафтове забруднення $\left(10 \pi / \mathrm{m}^{2}\right)$, рослини без гуматів; № 3 - контроль + фульвітал (обприскування); № 4 - контроль + гуміфілд (обприскування); № 5 - нафтове забруднення+фульвітал (замочення й обприскування); № 6 - нафтове забруднення+гуміфілд (замочення та обприскування) 
Варіант № 1

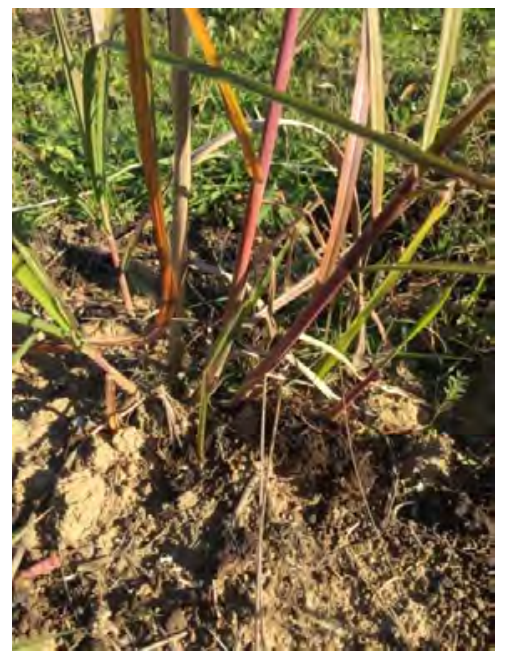

Варіант № 4

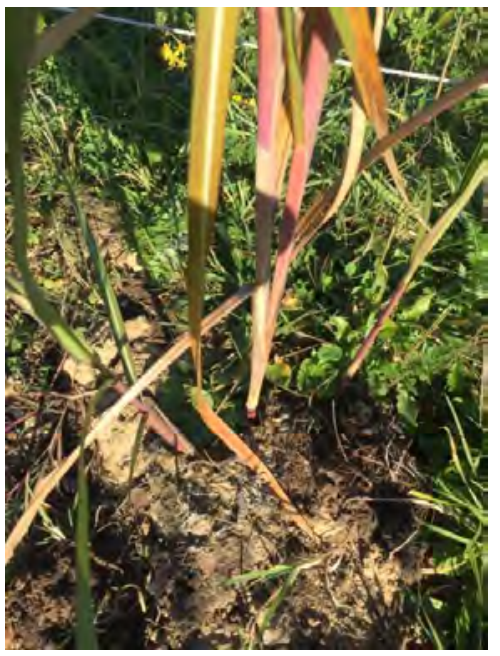

Варіант № 2

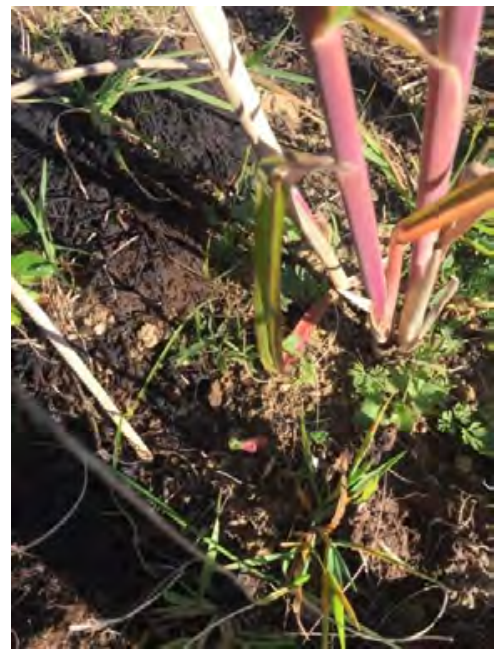

Варіант № 5

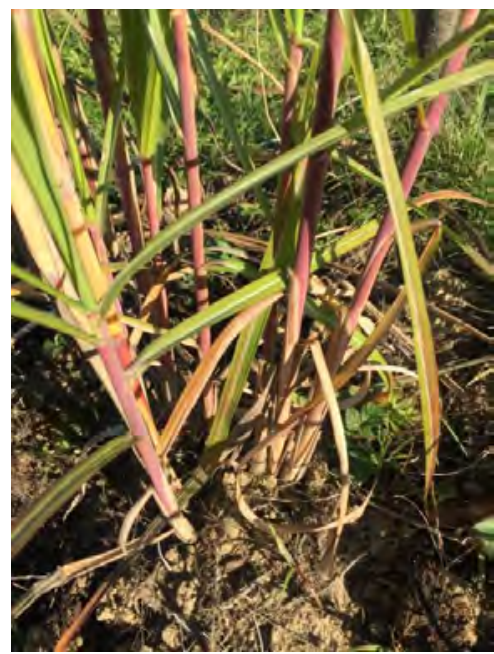

Bapiaнт № 3

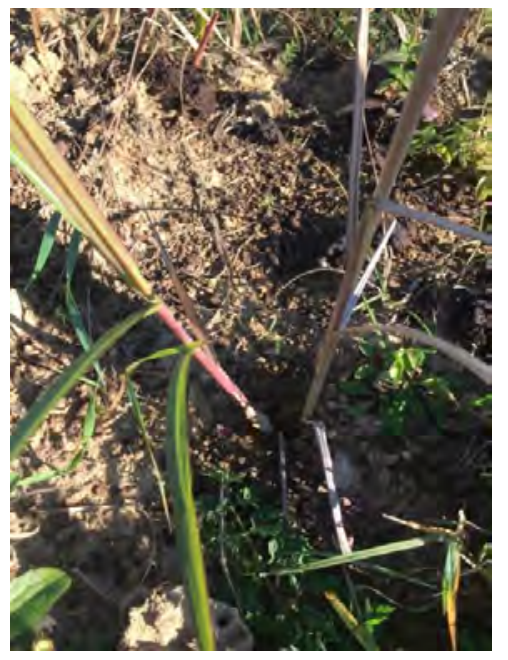

Варіант № 6

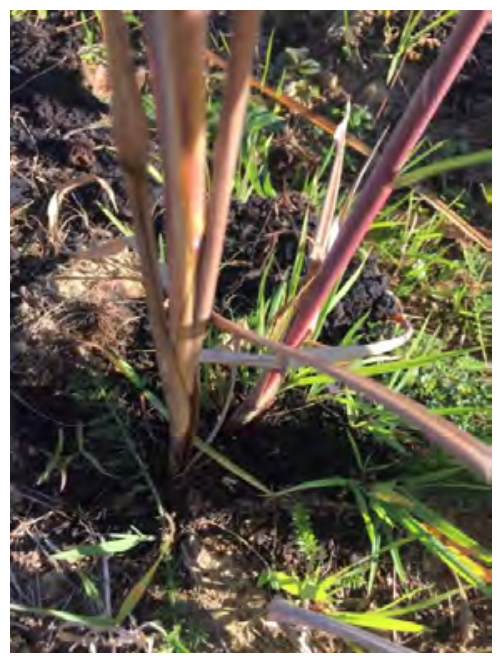

\section{Рис. 5. Рослини міскантусу за впливу нафтового забруднення й гуматів}

№ 1 - контроль (грунт без нафти, рослини без гуматів); № 2 - нафтове забруднення $\left(10 \pi / \mathrm{m}^{2}\right)$, рослини без гуматів; № 3 - контроль + фульвітал (обприскування); № 4 - контроль + гуміфілд (обприскування); № 5 - нафтове забруднення + фульвітал (замочування й обприскування); № 6 - нафтове забруднення + гуміфілд (замочування та обприскування) 
Таблиця 4

Ростові показники Miscánthus giganteus за впливу нафтового забруднення й гуматів

\begin{tabular}{|c|c|c|}
\hline Варіанти & $\begin{array}{c}\text { Висота } \\
\text { пагона, см }\end{array}$ & $\begin{array}{c}\text { Ширина } \\
\text { листків, см }\end{array}$ \\
\hline $\begin{array}{l}\text { № } 1 \text { - контроль (грунт без нафти, } \\
\text { рослини без гуматів) }\end{array}$ & $86,5 \pm 5$ & $1,5 \pm 0,1$ \\
\hline $\begin{array}{l}\text { № } 2-\text { нафтове забруднення } \\
(10 \text { л/м²), рослини без гуматів }\end{array}$ & $84,0 \pm 7$ & $1,4 \pm 0,1$ \\
\hline $\begin{array}{l}\text { № } 3 \text { - контроль (грунт без нафти + } \\
\text { фульвітал (обприскування)) }\end{array}$ & $75,0 \pm 4$ & $1,4 \pm 0,1$ \\
\hline $\begin{array}{l}\text { № } 4 \text { - контроль (грунт без нафти + } \\
\text { гуміфілд (обприскування)) }\end{array}$ & $80,0 \pm 5$ & $1,5 \pm 0,1$ \\
\hline $\begin{array}{l}\text { № } 5 \text { - нафтове забруднення + } \\
\text { фульвітал (замочення та } \\
\text { обприскування) }\end{array}$ & $108,3 \pm 15$ & $1,7 \pm 0,2$ \\
\hline $\begin{array}{l}\text { № } 6 \text { - нафтове забруднення + } \\
\text { гуміфілд (замочування та } \\
\text { обприскування) }\end{array}$ & $82,5 \pm 8$ & $1,4 \pm 0,1$ \\
\hline
\end{tabular}

Очевидно, що шкідливий вплив смолянисто-альфальтенових компонентів нафти на грунтові екосистеми змінює водно-повітряний режим і фізико-хімічні властивості грунту, а це призводить до порушення біодоступності елементів мінерального живлення для рослин і створює їх дефіцит. Тоді як фульвітал плюс - стимулятор росту й дефіцит-коректор елементів живлення рослин. Обприскування надземної частини фульвіталом забезпечувало позакореневе живлення міскантусу основними мінеральними елементами $(\mathrm{S}, \mathrm{Mg}, \mathrm{Fe}, \mathrm{Cu}, \mathrm{Mn}, \mathrm{Zn})$ і солями фульвових кислот, що могло стимулювати швидке нагромадження вегетативної маси й посилювати природний імунітет рослин в умовах нафтового стресу.

\section{ВИСНОВКИ}

Внаслідок інтенсивного і довготривалого нафтовидобутку й різних видів будівництва природний рельєф Старосамбірського нафтового родовища зазнав сильної антропогенної трансформації, виникли екологічні проблеми в екосистемах, зокрема в їхніх найважливіших компонентах - грунтах i рослинному покриві. Крім нафтового забруднення, спричиненого видобуванням, транспортуванням, наповнюванням автоцистерн, розливами нафтопродуктів, грунти Старосамбірського родовища зазнають додаткового впливу, як-от: витоптування й 
ущільнення автотранспортом, зміна гідрологічного режиму, деградація рослинних асоціацій. На основі отриманих результатів установлено ступінь забруднення й приблизну концентрацію нафти в досліджуваних пробах грунту Старосамбірського нафтового родовища: свердловина № 60 - максимальний рівень токсичності, дуже сильне забруднення (понад $10 \%$ нафти); свердловина № 65 - високий рівень токсичності, сильне забруднення (8-10 \% нафти); свердловина № 76 - рівень токсичності вищий за середній, середнє забруднення (6-8 \% нафти). Отже, грунти в регіоні потребують впровадження відповідних заходів і визначення оптимальних умов для проведення фіторемедіації.

У модельно-польових умовах вивчено вплив нафтового забруднення й гуматів (гуміфілд форте і фульвітал плюс) на ріст рослин Miscanthus giganteus.

Доведено, що обприскування гуматами надземної частини в процесі вегетації поліпшувало загальну життєздатність міскантусу в умовах нафтового забруднення: рослини активно нагромаджували біомасу, розвивали потужну кореневу систему й надземну частину, у листках збільшувався вміст фотосинтетичних пігментів. Отримані результати дослідження можуть бути використані для підвищення стресостійкості й урожайності міскантусу в умовах нафтового забруднення та під час розроблення фіторемедіаційних технологій відновлення нафтозабруднених територій.

\section{АНОТАЦІЯ}

Проведено моніторинг нафтозабруднених природних i штучних наземних екосистем Старосамбірського нафтового родовища. Вивчено рослинність і проаналізовано грунти ділянок нафтових свердловин № 60, 65,76 . Установлено ступінь забруднення грунтів i температурний режим, а також видовий склад рослин цих ділянок. Показано, що грунти, забруднені нафтою, мали вищу температуру порівняно 3 грунтом без нафти. Рослинний покрив запобігав перегріванню грунтів, температура на ділянках за участю рослин була нижчою в середньому на $3-5{ }^{\circ} \mathrm{C}$. Грунти в регіоні потребують детального дослідження та впровадження заходів для забезпечення поліпшення їхнього якісного стану, зокрема визначення оптимальних умов для проведення фіторемедіації (глава 1).

У штучних екосистемах (модельно-польовий дослід) вивчали методичні підходи до фіторемедіації нафтозабруднених грунтів 3 використанням рослин Miscanthus giganteus і застосуванням гуматів (гуміфілд форте і фульвітал плюс). Показано, що нафтозабруднені грунти пригнічували ріст рослин міскантусу. Застосування гуматів обприскування надземної частини в процесі вегетації - покращувало загальну життєздатність Miscanthus giganteus в умовах нафтового 
забруднення: рослини активно нагромаджували біомасу, розвивали потужну кореневу систему і надземну частину, в листках збільшувався вміст фотосинтетичних пігментів (глава 2).

Проведені дослідження можуть бути використані для розроблення фіторемедіаційних технологій відновлення нафтозабруднених територій.

\section{ЛIТЕРАТУРА}

1. Агрономічні аспекти вирощування міскантусу гігантського (Miscanthus giganteus) як сировини для виробництва твердого біопалива на забруднених внаслідок військової діяльності грунтах / Т. Р. Стефановська та ін. Біологічні студіï. 2017. Т. 11. № 3-4. С. 99-100.

2. Горова А., Кулина С. Оцінка токсичності грунтів Червоноградського гірничопромислового району за допомогою ростового тесту. Вісник Львівського університету. Серія «Біологія» 2008. Вип. 48. C. $189-194$.

3. Горон М. 3., Джура Н. М., Романюк О. I. та ін. Фітотестування як експрес-метод оцінки токсичності нафтозабруднених грунтів. Вісник Львівського університету. Серія «Біологія». 2012. Вип. 58. С. 185-192.

4. Губачов О. І. Особливості використання рослин для біотестування грунтів 3 метою визначення рівня екологічної безпеки промислових територій. Науковий вісник Кременчуцького університету економіки, інформаційних технологій та управління. Нові технології. 2010. № 3 (29). C. 164-171.

5. Джура Н. М. Можливості використання рослинних тест-систем для біомоніторингу нафтозабруднених грунтів. Біологічні Студї / Studia Biologica. 2011. T. 5. № 3. C. 183-196. DOI: https://doi.org/10.30970/ sbi.0503.176.

6. Джура Н. М., Подан I. I. Екологічна безпека територій Старосамбірського нафтового родовища. Екологічна безпека держави : збірка тез XIV Всеукраїнської науково-практичної конференції молодих учених і студентів, 23 квітня 2020 р. Київ, 2020. С. 68

7. Джура Н. М. Перспективи фіторемедіації нафтозабруднених грунтів рослинами Faba bona Medic. (Vicia faba L.). Вісник Львівського університету. Серія «Біологія». 2011. Вип. 57. С. 117-124.

8. Джура Н. М., Подан I. І. Екологічні наслідки довготривалого нафтовидобутку на Старосамбірському родовищі. Вісник Львівського університету. Серія «Біологія». 2017. Вип. 76. С. 120-127. DOI: http://dx.doi.org/10.30970/vlubs.2017.76.15.

9. Киреева Н. А., Мифтахова А. М., Кузяхметов Г. Г. Рост и развитие сорных растений в условиях техногенного загрязнения почвы. Вестник Башкирского университета. 2001. № 1. С. 32-34. 
10. Клімова Н. Деякі питання методики оцінки стану забруднення грунтів унаслідок нафтогазовидобутку. Вісник Львівського університету. Серія «Географія». 2006. Вип. 33. С. 144-151.

11. Концепція екологічного нормування допустимого антропогенного навантаження на грунтовий покрив / за ред. С. А. Балюка, М. І. Ромащенка. Київ : Аграрна наука, 2004. 34 с.

12. Вплив регуляторів росту рослин на адаптивні властивості Міскантусу гігантського (Miscanthus giganteus) для виробництва біомаси на грунтах, забруднених важкими металами / Медков А. та ін. Біологічні cmydiï. 2017. Том. 11. № 3-4. С. 100-101.

13. Определитель высших растений Украины / под ред. Д. Н. Доброчаева и др. Киев: Наукова думка, 1987. 548 с.

14. Спосіб фітоочищення нафтозабруднених грунтів : пат. 60481 Україна : МПК (2011.01) А01В 79/02 (2006.01) В09С 1/00. / Н. М. Джура, О. I. Романюк, О. М. Цвілинюк, О. І. Терек ; заявл. 01.11. 10; опубл. 25.06.11, Бюл. № 12, 2011.9 с.

15. Подан I. І., Джура Н. М. Вплив нафтового забруднення і гуматів на ріст рослин міскантусу. Екологічні науки : науково-практичний журнал. Київ : ДЕА, 2019. № 2 (25). С. 182-186. DOI https://doi.org/ 10.32846/2306-9716-2019-2-25-30.

16. Gorova A., Pavlychenko A., Kulyna S. Ecological problems of postindustrial mining areas. Geomechanical processes during underground mining. Leiden, The Netherlands : CRC Press. Balkema, 2012. P. 35-40. DOI https://doi.org/10.1201/b13157-7.

17. Pavlychenko A., Kovalenko A. The investigation of rock dumps influence to the levels of heavy metals contamination of soil. Mining of Mineral Deposits. Leiden, The Netherlands : CRC Press. Balkema, 2013. P. 237-238. DOI https://doi.org/10.1201/b13157-7.

18. Гумати - антистресова терапія для рослин. Агротехносоюз : веб-сайт. URL : www.agrotechnosouz.com.ua.

Information about authors:

Podan I. I.,

Postgraduate at the Department of Ecology Ivan Franko National University of Lviv 1, Saksagansky str., Lviv, 79005, Ukraine

Dzhura N. M., Candidate of Biological Sciences, Associate Professor, Associate Professor at the Department of Ecology Ivan Franko National University of Lviv 1, Saksagansky str., Lviv, 79005, Ukraine 